\author{
Jacek Kotus \\ Uniwersytet Adama Mickiewicza w Poznaniu \\ Instytut Geografii Społeczno-Ekonomicznej \\ i Gospodarki Przestrzennej \\ tatra@amu.edu.pl
}

\title{
BETWEEN ACCEPTANCE AND DISLIKE: THE INTRICACY OF CROSS-CULTURAL CONTACTS WHILE TRAVELLING
}

\begin{abstract}
Today travelling is a global phenomenon. Many journeys involve cross-cultural contacts, often between cultures which are very remote from each other. Some questions arise: does the contemporary traveller expect cross-cultural contacts and how does he/she imagine such interactions? These seemingly simple questions enable us to reflect on the intentionality and complexity of cross-cultural interactions, the main issue discussed in the article. The author draws the reader's attention to the social roles assumed by the modern traveller, as well as the theoretical scenarios of cross-cultural contact, analyzing its symmetric and asymmetric forms.
\end{abstract}

Key words: tourist, traveller, social roles, social behaviours, cross-cultural relations.

\section{HOMO VIATOR}

Man has always been engaged in two types of activity: settled, which allows him to develop 'horizontal' social structures; and nomadic, which gives him a chance to satisfy his need for expansion, discovery and learning. Man the wanderer, pilgrim and discoverer is one of the basic 'social profiles'. Homo viator, poetically personified by Odysseus on his 10-year journey, has been embodied by the leaders of great armies who took their soldiers to the ends of the ancient world, the discoverers and explorers of new lands and seas, pilgrims travelling to holy places, as well as Irish bards, and the French minstrels stopping at the inns, cities and courts of medieval Europe. For centuries, man has been setting out on expeditions or journeys.

However, in the $21^{\text {st }} \mathrm{c}$. the label Homo viator - the traveller - is attached to each of us like never before. It is given to those who want to pit themselves against the legendary travellers and explorers, as well as those who simply decide to spend their leisure time somewhere away from home. In the second half of the $20^{\text {th }}$ and in the early $21^{\text {st }} \mathrm{c}$. man can travel to the most remote places in the world and take up even the most extreme travelling challenges. Half a century ago, someone who visited the floating islands of Lake Titicaca was considered a great traveller, while today he is merely one of the hundreds or even thousands of tourists visiting this place (WEARING, STEVENSON \& YOUNG 2010). On the one hand, saying that the opportunity to travel is given to contemporary man in general is a certain overstatement, as it refers only to the inhabitants of developed countries and the richest from the Third World. On the other hand, however, the scale of movement in Asia and South America shows that travelling, as broadly understood in terms of moving from one place to another, also concerns the less affluent inhabitants of developing countries.

Well-developed and widespread travelling activity generates numerous economic, social and environmental issues, including those related to cross-cultural contacts. The aim of this article is to discuss the crosscultural relations which are formed when representattives of different cultures meet during individual and organized tourism trips.

According to the research presented at the $2^{\text {nd }}$ Congress on Travel Medicine in Warsaw ${ }^{1}, 75 \%$ of Europeans going to the tropics are interested in the climate and the living conditions in the country visited, and only $40 \%$ are interested in the medical situation there. With reference to these results, we may ask how many tourists pay attention to the different nature and complexity of the culture which they visit. How many realize what cross-cultural differences are? The answers to these questions may be surprising and show the contemporary tourist-traveller as a person who is often unprepared for cross-cultural interaction.

What social roles then can a contemporary wanderer assume while travelling and what significance does it have for cross-cultural contacts? 


\section{THE SOCIAL ROLES ASSUMED BY THE TOURIST-TRAVELLER}

Research interest in the social roles of travellers can be traced in the literature. The authors of Spatial Behaviour (Golledge \& Stimson 1999) established a five-degree typology of tourism behaviour, taking into consideration the relations which the visitors can have with the local community. They list the following psychological categories: allocentric, near allocentric, indirect, near psychocentric and psychocentric. The first two categories comprise those who are open to new experience, seek contacts with members of local communities, and often even try to become a part of these communities. In the indirect type, contact with locals is limited to tourism sites and situations such as buying souvenirs or using a local guide's services. The psychocentric type includes tourists who avoid contacts with representatives of other cultures, usually choose a familiar environment and go on trips mostly within their own country, even then avoiding interactions with the local population.

Researchers notice that most tourists represent the indirect type. It can be stated that in this case, if crosscultural contact occurs at all, it is the tourists who establish the rules and it is a very superficial interaction. It has nothing to do with really getting to know the person and their culture. It is more of a buyerseller relation set in the context of tourism service. Allocentric tourists comprise $6 \%$ of all tourists and near allocentric $15 \%$.

Other researchers who have studied the roles assumed by contemporary tourists, focus on the variety and distinctiveness of their behaviour towards the local population. The number of tourists and travellers has visibly increased in recent decades, therefore the issue has become more complex. New motives for travel are appearing, but the fact that it is so easy leads to a situation when a mentally unprepared tourist can find himself/herself in a culturally unfamiliar environment.

Cohen distinguishes between the institutionalized and non-institutionalized social roles of the tourist resulting from the growing participation of travel agencies in organizing tourism trips. Contrary to noninstitutionalized, open roles, institutionalized roles produce schematic and standardized behaviours (COHEN 1972).

Reviewing the motives for tourism activity and its social background, Urry stresses that a tourist coming from the 'Western World' travelled in a 'shelter' or 'cocoon', isolated from local cultures, as early as the 1970's (URRY 2002). While travelling, he was trying to remain in the company of tourists similar to him (consciously or subconsciously), and viewed the visited worlds from the perspective of someone visiting an open-air museum, or isolated himself at tourism resorts. At present, the issue of tourists colonizing selected regions of the world is becoming increasingly acute and obvious. Although in the overall number of those travelling, the number of 'true' travellers and tourists is also rising (COHEN 1979, PEARCE 1982), the predominant type is still the tourist having limited cross-cultural contact.

We may point to many regions in the world which are visited by millions of tourists every year; they are virtually invaded by visitors. One of the more evident manifestations of tourism colonization, sheltered areas and the transfer channels between them, is Indochina and the Bangkok - Angkor - Phnom Penh Saigon - Vientiane - Bangkok route. This includes four countries in which the tourist 'pops' into different tourist areas, finding there standardized hotels, clubs and restaurants. He moves between these areas, using a specially organized bus service. Using local transport is impossible in the deluge of tourist agencies' offers. The visitor travels through exotic countries, looking at different tourism products and has little chance of breaking free from this quasi-exotic circle.

The facts presented above prompt the following questions: are contemporary tourists able to make symmetrical relations with the local population at all and have a chance for peer interaction; having decided to assume the role of traveller, is the tourist condemned to superficial interaction and does he become dependent on the host's will; can he become a part of the local community if he makes an effort?

The two basic roles of those who travel to other cultures (places and people) can be described as the role of an 'insider' - a participant, and 'outsider' an observer (see Fig. 1). What characterizes these behaviours? The 'insider' is a 'participant' of the places and communities he visits. A person like this is able to enter a foreign culture, in a more or less conscious way. He does it either unconsciously, accepting the rules at the places visited and avoiding standard tourism routes and areas, or consciously immersing himself in non-tourist places. He provokes contacts with the locals and tries to glimpse the 'everydayness' of a foreign culture. The 'outsider' is a traveller, a tourist who consciously or unconsciously does not accept the visited culture, limiting himself to travelling in his 'cocoon'.

What are the chances of assuming one of these roles? A tourist becomes an 'insider' only when he consciously takes on this social role, while the role of an 'outsider' comes to him spontaneously, unintentionally. Every, or almost every, person setting out on a journey involuntarily becomes an 'outsider' at the places visited. He is a stranger (SIMMEL 2005) who packed his backpack, bought a ticket and was brave 
enough to leave his place of permanent residence and head for an unknown destination. In this situation, an 'outsider' is a priori an observer, someone who has to go through a number of rituals, sometimes very simple, in order to be at least partly accepted by local communities. Even in a situation when a tourist travels to a destination he is familiar with the truth is that on his next journey there he is still visiting the place after a certain period of absence. In the meantime, the place itself and its community will have changed for various reasons. He was absent, time was passing and human lives were changing.

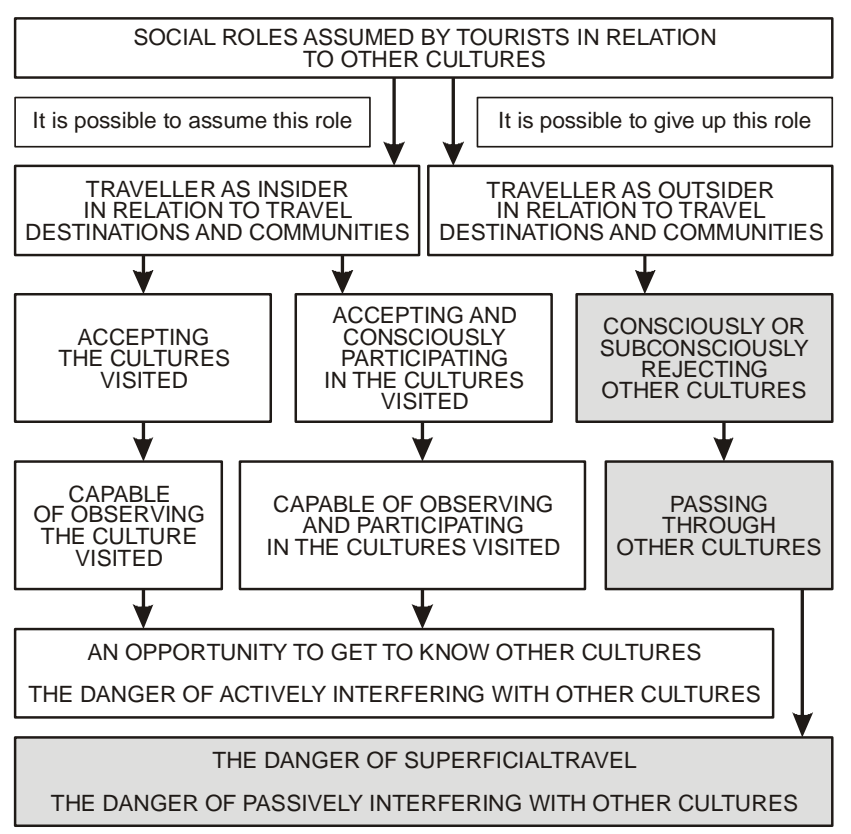

Fig. 1. Social roles assumed by tourists in relation to other cultures

The question arises whether the role of an 'insider' can be assumed during a journey. Travellers' accounts show that it is very difficult, and sometimes even impossible (CEJROWSKI 2003, URYN 2005, KASZA 2010). Certainly, in order to become an 'insider', at least partially, one needs to have a lot of patience, be aware of the norms and rituals of the other culture, repeatedly stay among the local community and have a little luck as well. As a result, the traveller may sometimes depend on being accepted by the members of the visited culture. The acceptance is likely to be incomplete, and the permission to learn the behavioural patterns of the local population and to take part in its life will be limited by different kinds of taboo (MAISONNEUVE 1995, BELL 209). It must be remembered, however, that assuming the role of a 'participant', living in a foreign culture or observing it from the inside, depends as much on the visitor's awareness as on the will of the local community.
Having assumed the role of an 'insider', the touristtraveller becomes either a mere observer of local life or a participant. As an 'outsider', the same tourist is only a person passing through a foreign culture, without reflecting on its existence.

In both cases, the cross-cultural contact may be threatening to members of the local community, as it may passively or actively interfere with or modify their behaviour. Theoretically speaking, such contact may also be dangerous to the visitors, though in reality the tourist adopts fewer elements of the foreign culture than the hosts (PODEMSKI 2004).

Certainly nowadays cross-cultural interactions are inevitable, and tourism, as broadly understood, is one of the basic domains of life in which these relations occur. We may ask, however, what steps are followed in such a contact - what scenarios are possible? (SMITH 1977, SMITH 2003).

\section{CROSS-CULTURAL CONTACT SCENARIOS}

Hypothetically, we may imagine four possible scenarios of cross-cultural contact, taking into consideration the involvement on the part of both the traveller and the host. This is of course a simplified set of social interactions which may be presented in a four-fold way (see Fig. 2).

- the scenario of a bilaterally open interaction - on the part of both the traveller and the host,

- the scenario of a unilaterally open interaction on the part of the traveller,

- the scenario of a unilaterally closed interaction on the part of the traveller,

- the scenario of bilaterally closed interaction - on the part of both the traveller and the host.

In the first case, the traveller and the host are in a bilaterally symmetrical relation and both parties form a harmonious system of cross-cultural interaction. This in practical terms means a contact based on the 'I speak and listen, approve and accept, I learn without changing' principle. It is a relation hard to achieve because the tourist-traveller is by definition a person who wants to learn and experience, is aggressive and takes too many things for granted, especially if he has devoted a lot of time, money and effort to reach the final destination and treats contact with members of the local community as the crowning of his efforts. In this situation he will be even more determined to arrange meetings, talk, take photographs, perhaps buy or exchange some small gifts. He may not realize that at the moment of contact his 'partner' in the interaction is in his/her everyday situation and has no time for or does not feel like inter- 
acting. Sometimes they are simply surprised by meeting a stranger and need time to get to know and place the 'newcomer' in their world. Let us add, a 'newcomer' who often does not know the local norms of everyday behaviour and, consequently, may cause as much damage to the culture as the proverbial 'bull in a china shop'.

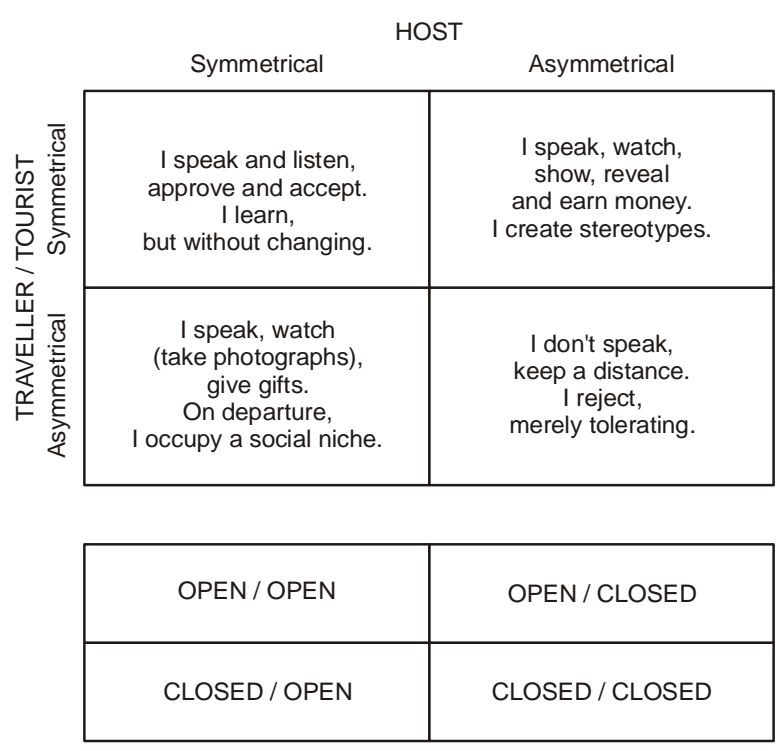

Fig. 2. Cross-cultural contact scenarios

The second scenario is a system of open behaviours and the attitude of a harmonious, symmetrical crosscultural contact, resulting from the visitor's actions. In other words, it is a meeting between a tourist who understands the complexity of cross-cultural contacts and who knows or wants to learn the rules of behaviour in the culture visited, and a host who is closed to interaction. A situation like this may occur when members of the local community have dealt with tourists before and learnt how to treat one so that he is satisfied and leaves money as a reward, or when the local population simply do not wish for any new contacts. In this scenario, interaction is either impossible or it takes place according to the host's rules; for two-three hours costume is worn and a superficial performance for visitors is given. This type of practice is represented by, for instance, the everyday tourist who visits by boat the Isla Taquile on Lake Titicaca. The island turns into a living open air museum for a few hours daily where the tourists may 'touch' the local culture for a small charge. On the one hand, it is a culture which actually exists, but on the other hand, it is slightly 'tuned' to meet the guests' needs and expectations. Such 'ethnic villages' are scattered all over the world and mark the trail of the most popular tourism destinations from Turkey to the Amazon Rainforest.
An interaction which is unilaterally closed on the part of the traveller is a set of behaviours, which may be summarized as 'I speak, watch, take photographs, give gifts and depart. I occupy a social niche'. This may be the most frequent form of relation characterized by asymmetry of contact on the part of the visitor. Consciously or not, he enters the visited culture bringing his habits, behavioural patterns and rituals with him. He is not oriented towards openness and presentation, but towards appropriating. The members of the local community, especially those who have never experienced contact with 'strangers' before, after meeting and getting used to them, decide to show them their everyday life. On the other hand, the tourist, perhaps unconsciously at times, arrives, shakes hands, takes photos, gives small gifts - often useless in the long run (a torch which stops working when they batteries run out, a ballpoint pen which eventually stops writing, etc.) and finally leaves. We may ask whether the contact which occurs has no significance, or despite being so superficial, affects the local population, changes its style of living and their attitudes to visitors.

Finally, the last of the scenarios is a unilaterally closed interaction, in which the tourist does not expect any particular contact with locals; he only takes advantage of the services they offer such as hunting, diving expeditions or another form of spending time and is not open to the local population. Both sides remain in the buyer-seller relationship and they do not expect to get to know each other. The tourist's main aim is to receive service of the standard he expects: a well-organized safari, a rafting or diving expedition, and that is what he focuses on during his contact with members of the local community. In this case, crosscultural contact certainly takes place, but as a cultural aspect it is moved to the background and it is significant only from the point of view of the communication between representatives of different cultures, as well as establishing and implementing the elements of a tourism service.

\section{CONCLUSIONS}

Quoting the results of research presented at the $2^{\text {nd }}$ Congress of Travel Medicine ${ }^{2}$ again, $6 \%$ of those returning from a tourist trip need medical help, 35\% of whom suffer from digestive discomfort, 8\% from respiratory problems and 5\% from injuries. With reference to the topic of this article we may ask how many tourists have suffered from cultural shock. How many of them start to dislike another culture because they do not understand it? How many tourists, when 
visiting exotic communities, make the mistake of feeling superior to their hosts?

A tourism trip associated with meeting those of other cultures is an example of a very complex interaction. It is an encounter with the representatives of sometimes completely different worlds. Both, the travellers and the hosts follow certain norms, have their own rituals and their culture of origin. Both often do not realize what they possess and what the cultural differences between them are. Moreover, the social role of the tourist and the host is characterized by certain attributes, mentioned in this text. The tourist, who breaks away from his 'usual', 'typical' daily routine and wants to learn and experience, is oriented towards something new, exotic, is expansive and demanding (often having stereotypical expectations, always exaggerated in some way), but he is also a stranger who does not know the rules of local life. The host, who performs his 'usual', 'typical' duties, wants to earn some money, sell, show but without disturbing his life with excessive openness, is rather defensive in his attitudes.

When going on a journey and meeting the members of a local community, one can assume different social roles and enter the interaction in a variety of ways. It is worth doing causing a minimum number of changes and to understand the cultural distinctness of others.

\section{FOOTNOTES}

1(http://www.rynekzdrowia.pl/Rynek-Zdrowia/II-KongresMedycyny-Podrozy-czyli-specjalisci-potwierdzaja-ze-Chorobynie-znaja-granic,52045.html) - accessed 28.04.2011.

2 Source: http://www.rynekzdrowia.pl/Rynek-Zdrowia/IIKongres-Medycyny-Podrozy-czyli-specjalisci-potwierdzaja-zeChoroby-nie-znaja-granic,52045.html, accessed on 28 th April 2011.

\section{BIBLIOGRAPHY}

BELL, C., 2009, Ritual: Perspectives and Dimensions, Oxford University Press, Oxford.

CEJROWSKI, W., 2003, Gringo wśród dzikich plemion, Poznaj Świat, Pelplin.

COHEN, E., 1972, Towards a Sociology of International Tourism, Social Research, 39, pp. 164-182.

COHEN, E., 1979, A Phenomenology of Tourist Experience. Sociology, The Journal of the British Sociological Association, 2, pp. 179-199.

GOLlEDGE, R.G, STIMSON, R.J., 1999, Spatial Behavior, The Guilford Press, New York.

KASZA, J., 2010, Duchy dżungli, Wyd. Otwarte, Kraków.

MAISONNEUVE, J., 1995, Rytuaty dawne i wspótczesne, GWP, Gdańsk.

PEARCE, P.L., 1982, The Social Psychology of Tourist Behaviour, A. Wheaton \& Co., Oxford.

PODEMSKI, K., 2004, Socjologia podróży, Wyd. Naukowe UAM, Poznań.

SIMMEL, G., 2005, Obcy, [w:] P. Sztompka, M. Kucia (eds), Socjologia - lektury, Znak, Kraków, pp. 580-583.

SMITH, M., 2003, Issues In Cultural Tourism Studies, Routledge, London.

SMITH, V. L., 1977, Hosts and Guests: The Antropology of Tourism, Blackwell, Oxford.

URRY, J., 2002, The Tourist Gaze, Sage, London, Thousand Oaks, New Delhi.

UrYN, B., A., 2005, Mongolia. Wyprawy w tajge i step, Poznaj Świat, Pelplin.

WEARING, S., STEVENSON, D., YOUNG, T., 2010, Tourist Cultures, Identity, Place and the Traveller, Sage, London, Thousand Oaks, New Delhi. 